\title{
PENGARUH KETINGGIAN TEMPAT TUMBUH PADA TANAMAN SEREH (Cymbopogon citrus) DAN AKTIVITAS ANTIBAKTERI Streptococcus mutans
}

\author{
Andi Nurpati Panaungi, Subehan Lallo, Herlina Rante, Gemini Alam, Sartini, Yulia Yusrini Djabir \\ Fakultas Farmasi, Universitas Hasanuddin, Makassar
}

Kata Kunci :

Sereh (Cymbopogon citrus (DC.) Stapf), Aktivitas antibakteri, Streptococcus mutans

\begin{abstract}
ABSTRAK
Tanaman sereh Cymbopogon citrus (DC.) Stapf merupakan salah satu tanaman sereh penghasil minyak atsiri yang digunakan sebagai antibakteri. Penelitian ini bertujuan untuk mengetahui pengaruh ketinggian tempat tumbuh dan aktivitas antibakteri. Masing-masing sampel dari ketinggian $935 \mathrm{~m} \mathrm{dol,}$ $260 \mathrm{~m} \mathrm{dpl}$, dan $10 \mathrm{~m}$ dpl didestilasi dengan metode destilasi uap air kemudian dilanjutkan pengujian antibakteri, analisis kualitatif menggunakan GCMS. Aktivitas antibakteri menggunakan metode Disc Diffusion Kirby-Bauer menggunakan medium MHA dengan waktu inkubasi selama 24 jam pada suhu $37^{\circ} \mathrm{C}$ terhadap bakteri Streptococcus mutans. Hasil penelitian menunjukkan bahwa minyak atsiri dari sereh yang paling baik aktivitas antibakteri terdapat pada ketinggian $935 \mathrm{~m}$ dpl yang memiliki adaya

hambat terhadap Streptococcus mutans sebesar 11,5 mm.
\end{abstract}

\section{PENDAHULUAN}

Indonesia termasuk negara yang penduduknya banyak menderita penyakit infeksi, salah satu penyebab penyakit infeksi yaitu bakteri (1). Bakteri akan berkembang atau resisten karena penggunaan antibiotik yang tidak rasional dan pemberian antibiotik dalam jangka waktu panjang sehingga menjadi ancaman utama bagi kesehatan masyarakat dan memerlukan solusi yang cepat untuk menangani masalah tersebut. Salah satu solusi yang dapat dilakukan dengan pencarian obat-obat antibakteri yang berasal dari antibiotik alami yang diperoleh dari ekstrak suatu tanaman tertentu yang memiliki khasiat sebagai obat (2).

Salah satu tanaman yang digunakan sebagai antibakteri yaitu tanaman sereh. Tanaman sereh (Cymbopogon citrus) merupakan tanaman yang cukup melimpah diindonesia. Tanaman ini mudah tumbuh pada berbagai jenis tanah yang memiliki kesuburan cukup dan tidak memerlukan perawatan khusus dan tanaman sereh ini merupakan tanaman penghasil minyak atrsiri yang memiliki peranan sebagai antibakteri yang akan menganggu proses terbentuknya membran sehingga tidak terbentuk sempurna minyak atsiri yang aktif sebagai antibakteri dari sereh mengandung gugus fungsi hidroksil $(-\mathrm{OH})$ dan Karbonil. Menurut (3) komponen senyawa utama minyak sereh terdiri dari sitronelal, sitrnellol dan geraniol. Kandungan sitronelal, geraniol dan sitronelol dalam minyak sereh mampu menghambat aktivitas bakteri Streprococcus mutans (4)

Efek farmakologi suatu tanaman obat tergantung pada senyawa kimia yang terkandung didalam tanaman tersebut. Sementara, kandungan senyawa kimia dalam tanaman dipengaruhi oleh faktor genetik, kondisi lingkungan (tempat tumbuh, iklim), perlakuan selama masa tumbuh, kondisi (umur dan cara panen). Kondisi lahan yang sesuai adalah pada ketinggian 100-600 m diatas permukaan laut ( $\mathrm{dpl})$, tetapi tanaman sereh masih dapat tumbuh dengan baik sampai ketinggian $1.200 \mathrm{~m}$ dpl dengan intesitas cahaya yang dibutuhkan $100 \%$, curah hujan yang sangat sesuai 2.000-3.000 mm (5). Waktu panen dilakukan pada pagi hari dengan cuaca yang cerah agar kandungan minyak esensial pada tanaman dapat dipertahankan, kandungan minyak paling optimal terdapat pada bagian daun (6).

Dari beberapa penelitian menunjukkan bahwa tanaman sereh mempunyai aktivitas antibakteri terhadap bakteri Streptococcus mutas.

Berdasarkan latar belakang diatas, maka peneliti tertarik ingin melakukan penelitian tentang pengaruh waktu panen pada tanaman sereh (Cymbopogon citrus) dan aktivitas antibakteri secara in vitro. Dimana bakteri yang digunakan adalah Streptococcus mutans.

\section{METODE PENELITIAN}

\section{Alat dan Bahan}

Alat-alat yang digunakan adalah Ose, , boto, spatel,, GCMS, laminar air flow, timbangan analitik, kondensor, kompor, statif dan klem, gelas ukur, labu ukur, tabung reaksi, elenmeyer, alat-alat gelas, busen, cawa petri, oven autoklaf(All American),inkubato(Memmert), jangka sorong, botol coklat, vial, gelas kimia, tissue, aluminium foil, masker, GPS (Global Position System).

Bahan yang digunakan adalah bakteri uji Streptococcus mutans ATCC 3568, sampel tanaman sereh (C.citrus.) , Amoksixilin, kapas, kain kasa steril, medium Brian Heart Infusion Broth (BHI-B), medium Muller Hilton Agar (MHA), spiritus, blank disk. 
Prosedur Kerja

\section{Penyiapan Sampel Penelitian}

Sampel penelitian yang digunakan berupa tanaman sereh (Cymbopogon citrus) yang berasal kabupaten bantaeng dengan 3 ketinggian yaitu $935 \mathrm{~m} \mathrm{dpl}, 260 \mathrm{~m}$ dpl dan $10 \mathrm{~m} \mathrm{dpl}$. Sampel yang telah dikumpulkan dicuci bersih dengan air mengalir, pencucian dilakukan agar tanaman bersih dari benda asing seperti tanah, pasir dan sebagainya. Kemudian diangin-anginkan dengan tujuan mencegah terjadinya pembusukan oleh bakteri atau jamur. Pembusukan terjadi karena berhentinya proses enzimatik dalam jaringan tumbuhan yang selnya telah mati, agar reaksi enzimatik tidak dapat berlangsung. Kemudian didestilasi dengan metode destilasi uap air sehingga menghasilkan minyak atsiri murni yang berwarna kuning jernih dengan bau yang khas dan menyengat dan mudah menguap. Sebelum dilakukan pengujian GC-MS dilakukan pemisahan dengan klorofom sehingga terjadi pemisahan lapisan dan lapisan air dibuang dan lapisan minyak diambil lalu dimurnikan dengan $\mathrm{Na} 2 \mathrm{SO} 4$ anhidrat. Kemudian dipekatkan sehingga diperoleh Minyak atsiri yang telah murni kemudian dimasukkan ke dalam botol lalu diidentifikasi senyawa aktif dengan menggunakan GCMS.

\section{Penyiapan Bakteri Uji}

\section{Pembuatan Suspensi Bakteri}

Biakan bakteri Streptococcus mutans diinokulasikan kedalam medium Nutrien Agar (NA) miring, diinkubasi pada suhu $37^{\circ} \mathrm{C}$ selama $1 \times 24$ jam. Bakteri yang tumbuh diambil 1 ose, dan diinokulasikan kedalam medium BHI-B dan diinkubasi pada suhu $37^{\circ} \mathrm{C}$ selama $1 \times 24$ jam. Kemudian dilakukan pengenceran sampai $10^{-1}$ sampai $10^{-3}$ selanjutnya diukur menggunakan spektrofotometer uv-vis dengan ketentuan OD600 $=1$. Setara dengan $1 \times 10^{8} \mathrm{sel} / \mathrm{ml}$.

\section{Uji Aktivitas Antibakteri}

Pengujian aktivitas minyak atsiri ditentukan dengan menggunakan metode difusi kertas cakram (Kirby-Bauer) dengan metode agar berapis. Lapisan pertama "Base Layer" tidak mengandung bakteri uji yang dicampurkan pada media MHA, kemudian dibiarkan memadat. Selanjutnya "Seed Layer" pada lapisan kedua mengandung bakteri uji yang dicampur kedalam media. Dibiarkan kering selama 5 menit. Kertas filter paper disc steril $6 \mathrm{~mm}$ diameter yang mengandung minyak atsiri $(2 \mathrm{mg} /$ disk $)$ kemudian ditempatkan pada permukaan lempeng agar. Plate diinkubasi pada suhu $37^{\circ} \mathrm{C}$ selama 24 jam. Aktivitas antibakteri dievaluasi dengan mengukur zona penghambatan dalam millimeter. Kertas paper disk yang berisi amoxicillin digunakan sebagai kontrol positif.

\section{HASIL DAN PEMBAHASAN}

Sampel sereh (Cymbopogon citrus (DC.) Stapf) ini dengan tiga ketinggian yaitu $935 \mathrm{~m} \mathrm{dpl}, 260 \mathrm{~m}$ dpl dan $10 \mathrm{~m} \mathrm{dpl}$, Pada penelitian ini menggunakan metode destilasi uap air. Dari proses destilasi uap air ini diperoleh minyak atsiri dengan warna kuning jernih, bau khas yang menyengat dan mudah menguap.dan diperoleh rendemen minyak atsiri dari tiap lokasi dengan waktu panen yang bervariasi dengan menunjukkan kadar minyak atsiri dari sereh sebesar 0,36 \% - 0,38\%. Dari penelitian ini diperoleh bahwa hasil rendemen yang diperoleh tidak berbeda nyata antara ketinggian $935 \mathrm{~m}$ $\mathrm{dpl}, 260 \mathrm{~m}$ dpl dan $10 \mathrm{~m} \mathrm{dpl}$ dan hasil rendeman yang paling besar yaitu sebesar 0,38 \%. Menurut (7) bahwa minyak sereh memiliki rendemen bervariasi sekitar 0,3\% - 1,0 \% (Tabel 1).

Profil kromatogram minyak atsiri dari sereh menunjukkan bahwa ketiga ketinggian tempat tumbuh yaitu ketinggian 935 $\mathrm{m}$ dpl, $260 \mathrm{~m}$ dpl dan $10 \mathrm{~m}$ dpl tidak berbeda nyata. Hasil kromatogram dengan menggunakan GCMS dapat dilihat pada gambar 1. Berdasarkan analisi profil kromatogram minyak atsiri dari sereh menggunakan GC-MS menunjukkan bahwa waktu retensi dari masing-masing ketinggian signifikan namun menghasilkan beberapa peak (puncak). Minyak atsiri dari sereh pada ketinggian $935 \mathrm{~m}$ dpl dan ketinggian $260 \mathrm{~m}$ dpl dengan menghasilkan 4 peak dengan luas area yang berbeda-beda, sedangkan minyak atsiri pada ketinggian $10 \mathrm{~m}$ dpl menghasilkan 5 peak dengan luas area yang berbedabeda. Hasil ini menunjukkan bahwa pada ketinggian $10 \mathrm{~m} \mathrm{dpl}$ kemungkinan besar senyawa mengalami dekomposisi karena adanya faktor intensitas sinar matahari yang mempengaruhi dan dipengaruhi oleh efek difusi karena terjadi pelebaran puncak pada ketinggian $10 \mathrm{~m}$ dpl dan adanya jumlah suatu komponen dalam sampel yang terjadi pada kolom yang berisi partikel yang tidak merata ukuran dan bentuknya sehingga jalan yang ditempuh komponen berbeda-beda sehingga menghasilkan luas puncak yang berbeda-beda. Menurut Rubiyanto, D. (2016) bahwa jumlah puncak yang dihasilkan dinyatakan sebagai jumlah komponen yang terdapat dalam sampel, sedangkan luas atau tinggi puncak menunjukkan adanya kuantitas atau jumlah suatu komponen dalam sampel, namun puncak yang melebar terjadi karena adanya efek difusi.

\begin{tabular}{ccccc}
\multicolumn{5}{c}{ Tabel 1. Minyak atsiri yang diperoleh dengan metode destilasi uap air } \\
\hline No & Ketinggian & $\begin{array}{c}\text { Berat } \\
\text { Sampel } \\
\text { (g) }\end{array}$ & $\begin{array}{c}\text { Berat } \\
\text { Minyak } \\
\text { Atsiri (ml } \\
\text { ) }\end{array}$ & $\begin{array}{c}\text { Rendamen } \\
\text { (\%) }\end{array}$ \\
\hline 1. & $935 \mathrm{~m} \mathrm{dpl}$ & 2000 & 8,4 & 0,38 \\
2. & $260 \mathrm{~m} \mathrm{dpl}$ & 2000 & 8.0 & 0.36 \\
3. & $10 \mathrm{~m} \mathrm{dpl}$ & 2000 & 8.4 & 0.38 \\
\hline
\end{tabular}

Tabel 2. Hasil Perbandingan waktu retensi dan persen luas area minyak sereh pada ketinggian $935 \mathrm{~m}$ dpl, ketinggian $260 \mathrm{~m}$ dpl dan ketinggian $10 \mathrm{~m}$ dpl dengan GC-MS

\begin{tabular}{ccc}
\hline Lokasi & RT & \% \\
\hline \multirow{3}{*}{$935 \mathrm{~m} \mathrm{dpl}$} & 6.41 & 16,3 \\
& 6.47 & 15,7 \\
& 6.61 & 6.0 \\
& 6.69 & 5.96 \\
\hline \multirow{2}{*}{$250 \mathrm{~m} \mathrm{dpl}$} & 6.41 & 33.3 \\
& 6.46 & 35,91 \\
& 6.60 & 29.3 \\
\hline \multirow{2}{*}{$10 \mathrm{~m} \mathrm{dpl}$} & 6.68 & 11.4 \\
& 6.41 & 48.2 \\
& 6.49 & 15,5 \\
& 6.60 & 12.9 \\
& 6.66 & 3.5 \\
& 6.71 & 15.1 \\
\hline
\end{tabular}

Dari hasil perhitungan luas area diperoleh rata-rata luas area dalam minyak atsiri pada sereh yang paling besar pada ketinggian $10 \mathrm{~m}$ dpl sebesar 48,2\% pada menit ke 6.41. Hal ini disebabkan pada ketinggian ini cahaya matahari yang diperoleh melimpah dan memilki pertumbuhan pada suhu yang maksimal yaitu $28^{\circ} \mathrm{C}$ dan semakin rendah suatu tempat atau lokasi tanam maka suhu yang ada dilokasi tersebut semakin tinggi dan intensitas sinar matahari melimpah sehingga laju fotosintesis dapat berjalan dengan maksimal. Menurut (8) bahwa tanaman sereh merupakan tanaman yang memerlukan iklim yang panas dengan cahaya matahari yang melimpah serta dapat tumbuh dengan maksimal pada suhu $23^{\circ} \mathrm{C}-30^{\circ} \mathrm{C}$. Pada ketinggian $935 \mathrm{~m}$ dpl diperoleh rata-rata luas area yang paling kecil sebesar $16,3 \%$ pada menit 6.41dikarenakan pada ketinggian ini tanaman sereh akan mengalami gangguan fisiologis yaitu laju fotosintesis tidak berjalan dengan maksimal karena kurangnya intesitas cahaya matahari yang diterima tanaman sereh, sedangkan pada ketinggian $260 \mathrm{~m}$ dpl tanaman sereh dapat tumbuh dengan 
baik karena suhu pada ketinggian ini cukup panas sehingga laju fotosintesis dapat berjalan dengan baik dan tinggi tanaman lebih tinggi dibandingkan pada ketinggian $935 \mathrm{~m}$ dpl.

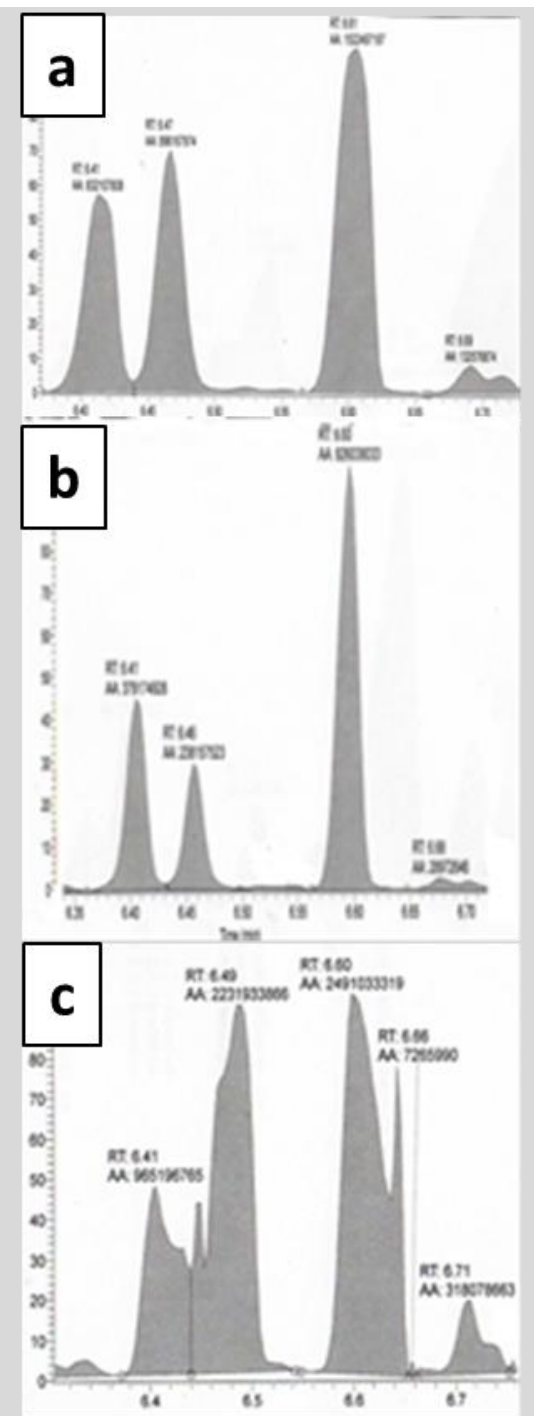

Gambar 1. Profil kromatogam minyak atsiri dari sereh dengan menggunakan GC-MS (A) ketinggian tempat tumbuh $935 \mathrm{~m}$ dpl, (b) ketinggian tempat tumbuh $260 \mathrm{~m}$ dpl dan (c) ketinggian tempat tumbuh $10 \mathrm{~m} \mathrm{dpl}$

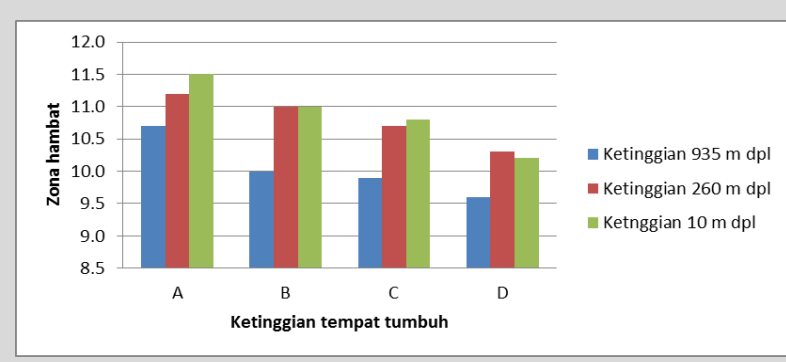

Gambar 2. Histogram uji aktivitas antibakteri minyak sereh terhadap bakteri Streptococcus mutans.

Pengujian aktivitas antibakteri dilakukan dengan metode difusi agar berlapis menggunakan dics cakram menggunakan kontrol positif Amoxicillin dan konsentrasi larutan uji $30 \%$ (b/v). Diamater yang ada disekitar disc diukur untuk melihat kekuatan hambatan obat terhadap bakteri uji. Berdasarakan hasil pengukuran daya hambat terhadap bakteri Streptococcus mutans dari masing-masing ketinggian tempat tumbuh $935 \mathrm{~m} \mathrm{dpl}, 260 \mathrm{~m}$ dpl dan $10 \mathrm{~m}$ dpl dapat dilihat pada gambar 2. Hasil pengujian aktivitas antibakteri terhadap bakteri Streptococcus mutans menunjukkan bahwa minyak atsiri pada sereh yang paling efektif digunakan sebagai antibakteri adalah ketinggian $10 \mathrm{~m}$ dpl dengan zona hambat sebesar 11,5 mm. Adanya perbedaan diameter hambat yang terbentuk dari masing lokasi menunjukkan adanya perbedaan senyawa aktif yang terdapat didalam minyak atsiri pada sereh yaitu citral dan geranial sehingga dapat menghambat pertumbuhan bakteri Streptococcus mutans. Aktivitas antibakteri dapat dipengaruhi oleh beberapa faktor yaitu faktor biologis dan faktor teknisi. Aktivitas antibakteri dipengaruhi oleh beberapa faktor yaitu kandungan senyawa antibakteri, jenis bakteri yang dihambat, konsentrasi ekstrak. Serta mutu ekstrak. selain itu juga faktor-faktor lingkungan seperti suhu udara, kelembapan, waktu panen, ketercukupan cahaya dalam proses fotosintesis yang sangat mempengaruhi fungsi fisiologis, bentuk anatomi dan siklus hidup tumbuhan. Dari hasil pengukuran diameter hambat terhadap bakteri Streptococcus mutans termasuk kategori kuat karena menurut ketentuan kekuatan daya antibakteri yaitu daerah hambatan $20 \mathrm{~mm}$ atau lebih berarti sangat kuat, daerah hambatan 10-20 mm berarti kuat, 5-10 $\mathrm{mm}$ berarti sedang, dan $5 \mathrm{~mm}$ atau kurang berarti lemah.

\section{KESIMPULAN}

Berdasarkan profil kromatografi GCMS, ketinggian tempat tumbuh memberikan pengaruh terhadap komponen kimia dan pada ketinggian $10 \mathrm{~m}$ di atas permukaan laut memperlihatkan aktivitas antibakteri yang lebih baik dengan diameter zona hambat terhadap Streptococcus mutans sebesar $11,5 \mathrm{~mm}$.

\section{UCAPAN TERIMA KASIH}

Penulis mengucapkan terima kasih kepada LPDP Indonesia Penulis mengucapkan terima kasih kepada LPDP Indonesia atas bantuan pendanaan. Penulis juga berterima kasih kepada Fakultas Farmasi Universitas Hasanuddin atas dukungan moril dan sarana selama penulis melakukan penelitian.

\section{DAFTAR PUSTAKA}

1. Radji, M. 2011. Buku Ajar Mikrobiologi. Panduan Mahasiswa Farmasi \& Kedokteran, Penerbit Buku Kedokteran ECG, Jakarta

2. Lewis, K. (2013). Platforms for antibiotic discovery. Nature reviews Drug discovey, 12(5), 371.

3. Burdock, G. 2002. Fanarali's Handbook of Flavor Ingredients. Boca Raton FL, CRC Press

4. Luangnarumitchai, S., Lamlertthon, S., \& Tiyaboonchai, W. 2007. Antimicrobial activity of essential oils against five strains of Propionibacterium acnes. Mahidol University Journal of Pharmaceutical Sciences. 34: 60-64

5. Rosman, 2012. Kesesuaian lahan dan iklim tanaman sereh wangi. Litbang Pertanian. Kementerian Pertanian. Jakarta. 65-70.

6. Sumiartha, K., Kohdrata, N., \& Antara, N. S. (2012). Budidaya dan Pasca Panen Tanaman Sereh (Cymbopogon citratus (DC.) Stapf.). Bali: Tropical Plant Curriculum Project

7. Sastrohamidjojo, H., 2004, Kimia Minyak Atsiri, Gadjah Mada University Press, Yogyakarta

8. Sofiah, Siti. 2010. Sereh Dapur Penghasil Minyak Atsiri. UPT Balai Konservasi Tumbuhan Kebun Raya Purwodadi-Lipi. 